\title{
Haptoglobins in chronic lymphatic leukaemia
}

\author{
S. S. PAPIHA, A. L. JONES, B. THOMPSON, and D. CARR \\ Department of Human Genetics, University of Newcastle upon Tyne and Department of Medicine, Royal \\ Victoria Infirmary, Newcastle upon Tyne
}

\begin{abstract}
Summary. Haptoglobin phenotypes have been determined in 30 chronic lymphatic leukaemia patients and concentrations determined in 21 of these. The number of $\mathrm{Hpl}$ phenotypes is slightly raised but not significantly so compared with a control population and is the same as that in first-degree relatives. Haptoglobin concentrations show higher concentrations in $\mathrm{Hp} 1$ than $\mathrm{Hp} 2$, as has previously been reported. It is concluded that haptoglobin genes contribute very little to any genetic influence on lymphatic leukaemia.
\end{abstract}

The possibility that the serum haptoglobin polymorphism, expressed in the three common phenotypes $\mathrm{Hp} 1, \mathrm{Hp} 2 \cdot 1$, and $\mathrm{Hp} 2$ (Smithies and Walker, 1956), is related to disease susceptibility has been the subject of a number of investigations (Giblett, 1969; Sutton, 1970). In particular several reports have suggested an association of haptoglobin phenotype with differential susceptibility to various forms of leukaemia.

In 1960, Latner and Zaki reported an increased number of $\mathrm{Hp1}$ phenotypes among 27 leukaemic patients, particularly marked among cases of chronic lymphatic leukaemia. They concluded that this distribution differed significantly from normal; and moreover there appears to be a significant disequilibrium in their phenotype numbers. A similar study of 35 patients by Galatius-Jensen (1962) showed an increased proportion of $\mathrm{Hpl}$ phenotypes over that in the normal Danish population but not significantly so, and there was no significant phenotype disequilibrium.

Since these early studies, several others have reported conflicting results. Peacock (1966) in Maryland showed an increased incidence of the Hpl phenotype in each of three different groups of leukaemia (chronic myelogenous, acute myelogenous, and acute lymphocytic), in which the haptoglobin type frequencies did not differ significantly from each other but overall differed significantly from the normal population of Maryland. Larkin (1967) included five leukaemic patients in a group of 36 suffering from reticuloses,

Received 14 January 1974. in a study of many different types of cancers, from which she concluded that the overall haptoglobin distribution in cancer patients is substantially similar to that in normal populations but that the reticuloses as a whole tend to have a higher $\mathrm{Hpl}$ gene frequency. Veale and Gunz (1967) showed a decreased incidence of the $\mathrm{Hpl}$ phenotype in 42 cases with frank chronic lymphatic leukaemia significantly different from that in a normal sample and deviating significantly from the number expected under Hardy-Weinberg equilibrium.

Some of these reports are complicated by the heterogeneous nature of the leukaemia groups studied. Moreover, comparison is not straightforward since the patients were drawn from different populations who may vary in their gene frequencies as well as their environments. In view of the inconsistency in the findings, an examination of haptoglobin phenotypes in chronic lymphatic leukaemia was made as part of a larger study of genetic and immunological factors in leukaemia.

\section{Materials and methods}

Blood specimens were obtained and the haptoglobin type identified in 30 patients, diagnosed as having chronic lymphatic leukaemia, resident in the north east of England. After separation serum was stored at $-20^{\circ} \mathrm{C}$ until haptoglobin typing and quantitation estimations were carried out.

Haptoglobin phenotypes were determined using horizontal starch gel electrophoresis, following the technique of Smithies using $11 \%$ hydrolysed starch (Connaught) with a discontinuous buffer system (Poulik, 1957). Upon completion of electrophoresis, the gel was sliced. 
TABLE I

HAPTOGLOBIN PHENOTYPES IN CHRONIC LYMPHATIC LEUKAEMIA PATIENTS

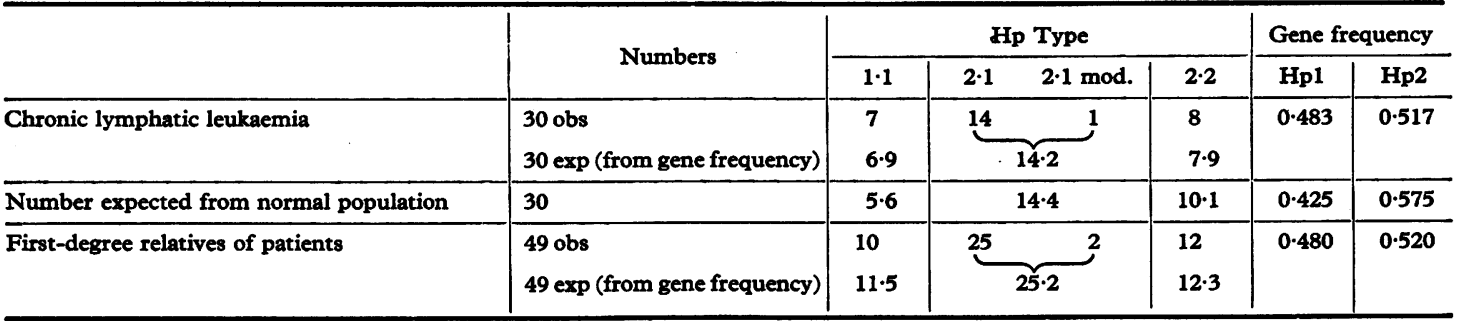

The upper half was stained with amido black to reveal the total protein pattern. The lower half was stained with a freshly prepared mixture of $0.2 \%$ benzidine in $0.5 \%$ acetic acid containing $0.2 \mathrm{ml} 30 \% \mathrm{w} / \mathrm{v}$ hydrogenperoxide. In order to stabilize the phenotype staining, $30-40 \mathrm{mg}$ ammonium chloride was added to the staining mixture. Polyacrilamide gel electrophoresis was used to check the phenotypes.

Quantitative estimates of haptoglobin activity were made on unhaemolysed serum samples using the peroxidase guaiacol method (Owen, Better, and Hoban, 1960).

Data for comparison are available on haptoglobin types in a sample of some 800 normal individuals born in different localities in the north east of England. Since there is local heterogeneity in gene frequency, in haptoglobin type as in ABO blood group (Roberts, 1953; Kopec, 1970), amongst the north-eastern populations, an expected frequency of haptoglobin types was calculated weighted to match the local distribution of the patients. Specimens were also obtained from first-degree relatives of the patients, mainly sibs, in order to provide a second comparable estimate of normal frequencies and to allow intrafamilial comparisons to be made.

\section{Results}

The phenotypes found in the 30 chronic lymphatic leukaemia patients are set out in Table I. In a further patient, not included in the present analysis, ahaptoglobinaemia was encountered, but in all the patients of the present study the types were clearly identified. The proportions of the haptoglobin alleles were determined by gene counting, and the equilibrium phenotype numbers expected, also shown in Table I, are very similar to those observed $\left(x^{2}=1 \cdot 02\right)$. Making comparison with the normal population, the numbers of phenotypes expected in a sample of 30 individuals, drawn from the same localities as the patients, are again very similar. There is a slight elevation of phenotype Hpl and diminution of type $\mathrm{Hp} 2$ in the patients, but this deviation is not significant $\left(x^{2}=0.82\right)$. There is a corresponding slight increase in the $\mathrm{Hp}^{1}$ allele frequency. The phenotype distribution in the first-
TABLE II

HAPTOGLOBIN CONCENTRATION

\begin{tabular}{|c|c|c|c|}
\hline & \multicolumn{3}{|c|}{ Hp Type } \\
\hline & $1 \cdot 1$ & $2 \cdot 1$ & $2 \cdot 2$ \\
\hline $\begin{array}{l}\text { Leukaemia patients } \\
\text { Present series } \\
\text { Number studied } \\
\text { Mean Hp concentration* } \\
\text { (mg/100 ml) } \\
\text { Standard deviation }(\mathrm{mg} / 100 \mathrm{ml}) \\
\text { Range (mg/100 ml) } \\
\text { Peacock (1966) } \\
\text { Number studied } \\
\text { Mean Hp concentration } \\
\text { Standard deviation } \\
\text { Range }\end{array}$ & $\begin{array}{c}5 \\
146 \\
39 \cdot 12 \\
95-200 \\
11 \\
146 \\
78 \\
75-330\end{array}$ & $\begin{array}{c}9 \\
93 \cdot 1 \\
37 \cdot 41 \\
50-140 \\
23 \\
130 \\
60 \\
29-238\end{array}$ & $\begin{array}{c}7 \\
50 \cdot 7 \\
31 \cdot 68 \\
25-110 \\
7 \\
128 \\
78 \\
46-244\end{array}$ \\
\hline $\begin{array}{l}\text { Normals } \\
\text { Smith and Owen (1961) } \\
\text { Mean } \\
\text { Standard deviation } \\
\text { Nyman (1958) } \\
\text { Mean } \\
\text { Standard deviation } \\
\text { Bayani-Sioson et al (1962) } \\
\text { Mean } \\
\text { Standard deviation } \\
\text { Murai (1960) } \\
\text { Mean }\end{array}$ & $\begin{array}{r}104 \\
34 \\
136 \\
30 \\
91 \\
21 \\
136\end{array}$ & $\begin{array}{r}102 \\
37 \\
\\
108 \\
37 \\
86 \\
22 \\
133\end{array}$ & $\begin{array}{l}72 \\
38 \\
82 \\
34 \\
69 \\
23 \\
92\end{array}$ \\
\hline
\end{tabular}

- Expressed as bound merhaemoglobin.

degree relatives, mainly sibs, pooled over all families is likewise similar, with an $\mathrm{Hp}^{1}$ allele frequency of 0.48 , almost identical to that in the patients. It appears therefore that there is no tendency for chronic lymphatic leukaemia to be associated with the $\mathrm{Hp} 1$ phenotype or the $\mathrm{Hp}^{1}$ allele.

The quantitative estimations of haptoglobin concentration in 21 of the chronic lymphatic leukaemia patients are shown in Table II. For comparison the data from normal individuals obtained by $D$ Smith and Owen (1961) using the same method, and by other investigators, are included. In the present $N$ series there appears a gradient in the mean concentration of haptoglobin, being least in haptoglobin phenotype 2 , and greatest in $\mathrm{Hpl}$. There is $\mathrm{C}$ indeed very little overlap in the concentration in the two homozygous categories, which are significantly 0 different. By comparison with the normal values, 
the Hp1 phenotype shows an increased mean haptoglobin concentration, and the $\mathrm{Hp} 2$ phenotype shows a marked decrease.

\section{Discussion}

The results on the different studies of haptoglobins in leukaemia are summarized in Table III. There is no general tendency for the numbers of phenotype Hp1 to be increased over those expected from the gene frequencies in the sample. There is a general but slight tendency for the $\mathrm{Hp} 1$ phenotype frequency to be elevated over that in the corresponding normal population in all studies except that of Veale and Gunz (1967), and in the studies of Peacock (1966) and Latner and Zaki (1960) this elevation is significant giving rise to a slightly increased $\mathrm{Hp} 1$ allele frequency. With this slight tendency the present findings are in agreement, but the same tendency is also shown in normal firstdegree relatives of the propositi, so it appears that either it is a chance effect or it is characteristic of the families in which cases occur rather than of the patients themselves.

Differentiating types, Latner and Zaki (1960) distinguish chronic lymphatic leukaemia as particularly demonstrating the tendency to increased $\mathrm{Hpl}$ phenotype, Veale and Gunz (1967) find the converse.
If observed and expected phenotype numbers in samples of chronic lymphatic leukaemia patients alone are pooled, there is no significant excess of phenotype Hp1, whether or not the sample of Veale and Gunz (1967) is included.

It is difficult to account for the significance of the findings of Veale and Gunz (1967) and Latner and Zaki (1960). Galatius-Jensen (1962) drew attention to the possibility that ahaptoglobinaemia may be mistaken for the $\mathrm{Hpl}$ phenotype. The lack of exactly comparable gene frequency data for the normal local populations from which the patients were drawn is another possible source of error. But the vagaries due to small sample numbers are notorious, and the small number of cases in each study may well be the explanation.

The gradient in mean haptoglobin concentration is not unexpected. All reports in normal subjects (Allison, 1958; Nyman, 1958; Murai, 1960; Smith and Owen, 1961; Bayani-Sioson et al, 1962) show $\mathrm{Hp} 2$ to have lower activity than the other phenotypes (the mean level in $\mathrm{Hpl}$ is higher than that in the heterozygote in almost all studies); Nyman (1958) showed a gradient as clear as in the present study. There are no significant differences between our activities and his in phenotypes $\mathrm{Hp} 1$ and $\mathrm{Hp} 2 \cdot 1$, but that in our Hp2 phenotype is appreciably lower. The cause of this variation between phenotypes in

TABLE III

HAPTOGLOBIN TYPES IN LEUKAEMIA STUDIES

\begin{tabular}{|c|c|c|c|c|c|}
\hline & \multicolumn{3}{|c|}{ Hp Type } & \multirow{2}{*}{$\begin{array}{c}\text { Total } \\
\text { Tested }\end{array}$} & \multirow{2}{*}{$\begin{array}{l}\text { Hp Allele } \\
\text { Frequency }\end{array}$} \\
\hline & $1 \cdot 1$ & $2 \cdot 1$ & $2 \cdot 2$ & & \\
\hline $\begin{array}{l}\text { Present study } \\
\text { No. obs } \\
\text { No. exp from sample allele frequency } \\
\text { No. exp from normal population distribution }\end{array}$ & $\begin{array}{l}7 \\
6 \cdot 9 \\
5 \cdot 6\end{array}$ & $\begin{array}{l}15 \\
14 \cdot 2 \\
14 \cdot 4\end{array}$ & $\begin{array}{r}8 \\
7 \cdot 9 \\
10 \cdot 1\end{array}$ & 30 & $\begin{array}{l}0.483 \\
0.425\end{array}$ \\
\hline $\begin{array}{l}\text { Veale and Gunz (1967) } \\
\text { No. obs } \\
\text { No. exp from allele frequency } \\
\text { No. exp from normal population distribution* }\end{array}$ & $\begin{array}{l}1 \\
4 \cdot 7 \\
6 \cdot 1\end{array}$ & $\begin{array}{l}26 \\
18 \cdot 7 \\
19 \cdot 4\end{array}$ & $\begin{array}{l}15 \\
18 \cdot 7 \\
16 \cdot 4\end{array}$ & 42 & $\begin{array}{l}0.333 \\
0.38\end{array}$ \\
\hline $\begin{array}{l}\text { Galatius-fensen (1962) } \\
\text { No. obs } \\
\text { No. exp from allele frequency } \\
\text { No. exp from normal population distribution }\end{array}$ & $\begin{array}{l}8 \\
7 \cdot 3\end{array}$ & $\begin{array}{l}14 \\
15 \cdot 5 \\
11 \cdot 4\end{array}$ & $\begin{array}{r}9 \\
8 \cdot 3 \\
14 \cdot 6\end{array}$ & 31 & 0.40 \\
\hline $\begin{array}{l}\text { Larkin (1967) } \\
\text { No. obs } \\
\text { No. exp from allele frequency } \\
\text { No. exp from normal population distribution }\end{array}$ & $\begin{array}{l}7 \\
6 \cdot 7 \\
5 \cdot 4\end{array}$ & $\begin{array}{l}17 \\
17 \cdot 7 \\
17 \cdot 2\end{array}$ & $\begin{array}{l}12 \\
11 \cdot 6 \\
13 \cdot 4\end{array}$ & 36 & $\begin{array}{l}0.430 \\
0.389\end{array}$ \\
\hline $\begin{array}{l}\text { Latner and } Z a k i(1960) \\
\text { No. obs } \\
\text { No. exp from allele frequency } \\
\text { No. exp from normal population distribution }\end{array}$ & $\begin{array}{l}12 \\
2 \cdot 6\end{array}$ & $\begin{array}{r}8 \\
13\end{array}$ & $\begin{array}{c}7 \\
10 \cdot 4\end{array}$ & 26 & $\begin{array}{l}0.60 \\
0.35\end{array}$ \\
\hline $\begin{array}{l}\text { Peacock (1966) } \\
\text { No. obs (leukaemia all types) } \\
\text { No. exp from allele frequency } \\
\text { No. exp from normal population distribution }\end{array}$ & $\begin{array}{l}18 \\
20 \cdot 2 \\
9 \cdot 9\end{array}$ & $\begin{array}{l}44 \\
39 \cdot 5 \\
34 \cdot 9\end{array}$ & $\begin{array}{l}17 \\
19 \cdot 3 \\
34 \cdot 1\end{array}$ & 79 & $\begin{array}{l}0.506 \\
0.346\end{array}$ \\
\hline
\end{tabular}

* These authors do not state normal frequencies, so figures from other samples of New Zealand whites are inserted here. 
normals is not known. Its apparent enhancement in the present study may be a result of the drug therapy received by the patients, as most were receiving prednisone and chlorambucil at the time of blood collection. However, in no patients included in the present study was the activity so low as to inhibit identification of phenotype.

The results therefore indicate that the haptoglobin genes are contributing very little to the genetic influence on the disease previously shown by Miller (1964), Steinberg (1960), and Damsehek and Gunz (1964) in family studies.

Acknowledgment is gratefully made to the North of England Council of the British Empire Cancer Campaign for financial support.

Our thanks are also due to Dr D. F. Roberts for his continuing help and advice during this work.

\section{REFERENCES}

Allison, A. C. (1958). The genetical and clinical significance of the haptoglobins. Proceedings of the Royal Society of Medicine, 51, 641-645.

Bayani-Sioson, P. S., Louch, J., Sutton, H. E., Neel, J. V., Horne, S. L., and Gershowitz, H. (1962). Quantitative studies on the haptoglobins of apparently healthy adult male twins. American fournal of Human Genetics, 14, 210-219.

Damsehek, W. and Gunz, F. (1964). Leukemia, 2nd ed., pp. 63114. Grune and Stratton, New York.

Galatius-Jensen, F. (1962). The use of the serum haptoglobin patterns in cases of disputed paternity. Methods of Forensic Science, 1, 497-5.38.
Giblett, E. R. (1969). Genetic Markers in Human Blood. Blackwell, Oxford.

Kopec, A. C. (1970). The Distribution of Blood Groups in the United Kingdom. Oxford University Press, London.

Larkin, M. F. (1967). Serum haptoglobin type and cancer. fournal of the National Cancer Institute, 39, 633-638.

Latner, A. L. and Zaki, A. H. (1960). Clinical uses of starch gel electrophoresis with special reference to leukaemia. Clinica Chimica Acta, 5, 22-25.

Miller, R. W. (1964). Radiation, chromosomes and viruses in the etiology of leukemia. Evidence from epidemiological research. New England fournal of Medicine, 271, 30-36.

Murai, K. (1960). Genetic studies on haptoglobin types. Japanese fournal of Human Genetics, 5, 205-223.

Nyman, M. (1958). Über Haptoglobinbestimmung im Serum, Normalkonzentration und Verhältnis zu Smithies Serumgruppen. Clinica Chimica Acta, 3, 111-113.

Owen, J. A., Better, F. C., and Hoban, J. (1960). A simple method for the determination of serum haptoglobins. Fournal of Clinical Pathology, 13, 163-164.

Peacock, A. C. (1966). Serum haptoglobin type and leukemia: an association with possible etiological significance. Fournal of the National Cancer Institute, 36, 631-639.

Poulik, M. D. (1957). Starch gel electrophoresis in a discontinuous system of buffers. Nature, 180, 1477-1479.

Roberts, J. A. Fraser (1953). An analysis of the ABO blood group records of north of England. Heredity, 7, 371-388.

Smith, H. and Owen, J. A. (1961). The determination of haptoglobins in normal human serum. Biochemical fournal, 78, 723728.

Smithies, O. and Walker, N. F. (1956). Notation for serum-protein groups and the genes controlling their inheritance. Nature, 178, 694-695.

Steinberg, A. G. (1960). Genetics of acute leukemia in children. Cancer, 13, 985-999.

Sutton, H. E. (1970). The haptoglobins. In Progress in Medical Genetics, vol. 7, ed. by A. G. Steinberg, and A. G. Bearn, pp. 163202. Grune and Stratton, New York.

Veale, A. M. O. and Gunz, F. W. (1967). Haptoglobins and leukaemia. Proceedings of the University of Otago Medical School, 45 36-38. 